F. W. Fitzke, D. Pauleikhoff et al. // Invest. Ophthalmol. Vis. Sci. - 1992. - Vol. 33. - P. 334-40.

9. Das A. Retinal and choroidal angiogenesis: pathophysiology and strategies for inhibition / A. Das, P. G. McGuire // Prog Retin Eye Res. - 2003. - Vol. 22. - P. 721-48.

10. Guymer R. Changes in Bruch's membrane and related structures with age / R. Guymer, P. Luthert, A. Bird
// Prog Retin Eye Res. - 1999. - Vol. 18. - P. 5990.

11. Zarbin M. A. Current concepts in the pathogenesis of agerelated macular degeneration / M. A. Zarbin // Arch Ophthalmol. - 2004. - Vol. 122. - P. 598-614.

Поступила 21.10.2012

Рецензент д. М. Н. В. В. Савко

\title{
BLOOD SUPPLY DISTURBANCE IN THE OCULAR VASCULAR MEMBRANE IN PATIENTS WITH EXUDATIVE AGE-RELATED MACULAR DEGENERATION
}

\section{A. R. Korol, N. I. Khramenko, T. B. Kustrin}

Odessa, Ukraine

Ocular hemodynamics of patients with exudative AMD, according to ROG (RQ or $\alpha / T)$ was disturbed in all patients. A decrease of RQ was noted in $769 \%$ of cases, changes (increase or decrease) of $\alpha / \mathrm{T}$ was noted in $95.4 \%$ of cases. Zones of choroidal hypofluorescence according to FAG were diagnosed in $67.7 \%$ of cases in patients with exudative AMD.

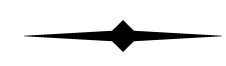

УдК 617.736-007-053.9-085:612.015.13

\section{ВЛИЯНИЕ ФЛОГЕНЗИМА НА АКТИВНОСТЬ ПРОТЕОЛИТИЧЕСКИХ ФЕРМЕНТОВ КРОВИ У БОЛЬНЫХ ВОЗРАСТНОЙ ДЕГЕНЕРАЦИЕЙ МАКУЛЫ}

\author{
А. А. Онищенко, врач, В. В. Савко, д. М. Н., Т. В. Пархоменко, ст. лаб. \\ ГУ «Институт глазных болезней и тканевой терапии им. В. П. Филатова АМН Украины» \\ Одесса, Украина
}

\begin{abstract}
Клінико-біохімічні дослідження проведені у 89 хворих з віковою дегенерацією макули: основна (46 хворих) і контрольна (43 хворих) групи. Вживання Флогензіма в основній групі підвищило показники сумарної протеолітичної активності на 36,6 \% і знизило показники антіпротеазної активності на 24,6 \% в порівнянні з контрольною групою після лікування. Отримані результати обгрунтовують перспективність вживання препаратів системної ензимотерапії в комплексному лікуванні хворих з віковою дегенерацією макули.
\end{abstract}

Ключевые слова: возрастная дегенерация макулы, суммарная протеолитическая активность крови, антипротеазная активность, флогэнзим

Ключові слова: вікова дегенерація макули, сумарна протеолітична активність крові, антіпротеазна активність крові, флогензім.

Введение. Несмотря на значительные усилия, направленные в течение последних десятилетий на изучение патогенеза возрастной дегенерации макулы (ВДМ) и разработку новых средств ее консервативного лечения и профилактики, распространение этого заболевания продолжает возрастать. В этой связи актуальным остается поиск новых и усовершенствование существующих способов медикаментозной профилактики и лечения ВДМ $[1,10,17]$.

Согласно литературным данным, в этиопатогенезе возрастной дегенерации макулы имеют значение различные факторы, в частности, накопление продуктов обмена веществ в пигментном эпителии, утолщение мембраны Бруха, атеросклеротические изменения в сосудах хориокапиллярного слоя и нарушение микроциркуляции в сосудах хориоидеи $[5,12,13,18]$.
Убывающая с возрастом активность антиокислительной системы и недостаток основных питательных веществ могут приводить к развитию дегенеративных изменений в тканях глаза. На основании данного предположения, снижение активности защитной антиоксидантной системы и ухудшение метаболизма в пожилом возрасте означает, что свободные радикалы, которые при «нормальном» обмене вешеств немедленно разрушаются как промежуточный продукт, в данных условиях вызывают повреждение клеток, приводя к их гибели [2, 6, 9, $14,16]$.

В ряде исследований получены данные о снижении концентрации антиоксидантов в организме

(C) А. А. Онищенко, В. В. Савко, Т. В. Пархоменко, 2012 
больных с возрастной дегенерацией макулы. В то же время доказано наличие изменений активности ферментов антирадикальной защиты $[7,15]$.

В последние годы выдвинута новая концепция, согласно которой, в патогенезе возрастных заболеваний органа зрения важным элементом наряду со свободно-радикальными повреждением белков и нарушением антиоксидантной системы, является процесс протеолитической деградации поврежденных белковых структур и их удаление из тканей.

В норме высокоактивная система протеолиза сбалансирована с помощью регуляторов - специфических эндогенных ингибиторов, которые обнаружены в плазме крови. Ингибиторы быстро связывают различные протеиназы, инактивируя их полностью или частично [3].

Нами в экспериментальных исследованиях было выявлено положительное влияние препаратов системной энзимотерапии на патологические изменения в сетчатке, развившиеся при световом воздействии, а также их активирующее влияние на протеазно-ингибиторную систему. Последняя, как известно, является вторым барьером защиты от оксидативного поражения тканей [8].

Цель настоящей работы заключалась в изучении влияния Флогензима на активность протеолитических ферментов в крови больных с возрастной дегенерацией макулы.

МАТЕРИАЛ И МЕТОДЫ ИССЛЕДОВАНИЙ. Клинические исследования проведены у 89 больных с диагнозом возрастная дегенерация макулы.

В процессе лечения выделено две группы больных: основная (46 больных) и контрольная (43 больных). В комплексное лечение всех больных входили: антиоксиданты, десенсибилизирующие, сосудорасширяющие препараты, тканевые препараты, витамины в течение 2-х месяцев.

Больным основной группы дополнительно назначали препарат флогензим в течение 2 -х месяцев по 2 таб. 3 раза в день (суточная доза препарата составляла 1428 мг).

Офтальмологическое обследование больных проводили с помощью визиометрии, периметрии, тонометрии, офтальмоскопии.

В крови больных производили определение суммарной протеолитической и антипротеазной активности до, в средние сроки (1 месяц) и после ( 2 месяца) лечения. Эти исследования также были проведены у 35 здоровых лиц-волонтеров, показатели которых использовали в качестве нормы.

Методика определения суммарной протеолитической активности [3, 11].

Принцип метода основан на определении аргининсодержащих пептидов, которые отщепляются от щелочного белка протамина протеолитическими ферментами, что позволяет определить эндогенную протеолитическую активность биологического материала, проявляемую протеиназами с трипсиноподобной активностью (плазмин, калликреин) и ферментами пептидазного действия.

Суммарную протеолитическую активность рассчитывали в нкат/мл плазмы или г ткани: $\mathrm{A}=\frac{a \cdot b \cdot 3600 \cdot 1000}{v \cdot t \cdot 174,2 \cdot 1000}$.
Количество отщепленного аргинина рассчитывали с помощью предварительно построенной калибровочной кривой зависимости оптической плотности от количества аргинина.

Суммарную протеолитическую активность выражали в производных катала (нкат), т. е. в молях субстрата, превращенного в процессе ферментативного гидролиза за одну секунду на единицу объема плазмы или сырой массы ткани.

Методика определения антипротеазной активности $[3,11]$.

Принцип метода основан на способности биологического материала (содержащего фермент трипсин) тормозить расщепление трипсином N-бензоил-DL-аргинин-pнитроанилида (БАПНА).

Антипротеазную активность рассчитывали в нкат/мл плазмы или г ткани: $\mathrm{A}=\frac{\Delta \boldsymbol{E} \cdot \boldsymbol{K} \cdot \Phi}{v \cdot \boldsymbol{t} \cdot \boldsymbol{E}}$.

Статистическая обработка материалов производилась программой «Statistica 10,0» с определением среднего значения показателей М и ошибки среднего показателя $\mathbf{m}$, уровень значимости различий показателей оценивался по критерию Стьюдента - $\mathbf{t}$ для независимых и зависимых выборок [4].

РЕЗУЛЬТАТЫ И ИХ ОБСУЖДЕНИЕ. ДаННЫе о показателях суммарной протеолитической активности крови у больных с возрастной дегенерацией макулы контрольной и основной групп представлены в таблице 1.

У всех исследованных больных ВДМ отмечается достоверное снижение протеолитической активности крови относительно нормы (в контрольной группе на 33,8 \%, в основной 30,9 \% соответственно).

Проведение дедистрофической терапии, включающей трентал, актовегин, милдронат, церебрум-композитум, тиотриозолин, нейрорубин, не вызывает существенных изменений состояния протеолитической активности крови больных ВДМ. Включение Флогензима в традиционную схему медикаментозного лечения повысило протеолитическую активность крови больных ВДМ в основной группе в процессе лечения на 19,1\% и относительно контрольной группы на $36,6 \%(\mathrm{p}<0,05)$.

Параллельно с повышением протеолитической активности крови у больных ВДМ отмечается снижение антипротеазной активности крови, которая достоверно выше как в основной, так и в контрольной группах относительно нормы (на 34,3 и 31,0 \% соответственно).

В процессе лечения в контрольной группе антипротеазная активность крови (ААК) остается высокой (табл. 2). В основной группе больных, получавших Флогензим , ААК достоверно снижается на $22,1 \%(\mathrm{p}<0,01)$ в процессе лечения.

Сравнительно с больными контрольной группы, в основной группе больных ААК после лечения с применением Флогензима снизилась на 24,6\% $(\mathrm{p}<0,001)$ и практически достигла нормы $(5,42 \pm 0,3)$ и $(5,67 \pm 0,32)$ соответственно. 
Суммарная протеолитическая активность крови у больных с возрастной дегенерацией макулы контрольной и основной групп до и после лечения (нкат/мл)

\begin{tabular}{|c|c|c|c|c|c|c|c|}
\hline \multirow{2}{*}{$\begin{array}{c}\text { Статистический } \\
\text { показатель }\end{array}$} & \multirow{2}{*}{$\begin{array}{c}\text { Группа } \\
\text { здоровых лиц. } \\
\text { Норма }\end{array}$} & \multicolumn{3}{|c|}{ Контрольная группа } & \multicolumn{3}{|c|}{ Основная группа } \\
\hline & & До лечения & $\begin{array}{c}\text { Средний } \\
\text { срок }\end{array}$ & $\begin{array}{c}\text { После лече- } \\
\text { ния }\end{array}$ & До лечения & $\begin{array}{c}\text { Средний } \\
\text { срок }\end{array}$ & $\begin{array}{c}\text { После лече- } \\
\text { ния }\end{array}$ \\
\hline $\mathrm{n}$ & 35 & 43 & 43 & 43 & 46 & 46 & 46 \\
\hline $\mathrm{M} \pm \mathrm{m}$ & $0,68 \pm 0,04$ & $0,45 \pm 0,03$ & $0,42 \pm 0,04$ & $0,41 \pm 0,04$ & $0,47 \pm 0,04$ & $0,52 \pm 0,05$ & $0,56 \pm 0,05$ \\
\hline p1 & - & $<0,001$ & $<0,001$ & $<0,001$ & $<0,001$ & $<0,01$ & $>0,05$ \\
\hline$\% 1$ & 100,0 & 66,2 & 61,8 & 60,3 & 69,1 & 76,5 & 82,4 \\
\hline p2 & - & - & $>0,05$ & $>0,05$ & - & $<0,05$ & $<0,05$ \\
\hline$\% 2$ & - & 100,0 & 93,3 & 91,1 & 100,0 & 110,6 & 119,1 \\
\hline p3 & - & - & - & - & $>0,05$ & $>0,05$ & $<0,05$ \\
\hline$\% 3$ & - & 100,0 & 100,0 & 100,0 & 104,4 & 123,8 & 136,6 \\
\hline
\end{tabular}

Примечания: p1 - достоверность различий данных по отношению к норме, рассчитанный с помощью t-критерия для независимых выборок; р2 - достоверность различий данных по отношению к исходным данным, рассчитанный с помощью t-критерия для зависимых выборок; р3 - достоверность различий данных между группами контрольной и основной в зависимости от срока наблюдения, рассчитанный с помощью t-критерия для независимых выборок.

Таблица 2

Показатели антипротеазной активности крови у больных с возрастной дегенерацией макулы контрольной и основной групп до и после лечения

\begin{tabular}{|c|c|c|c|c|c|c|c|}
\hline \multirow{2}{*}{$\begin{array}{c}\text { Статистический. } \\
\text { показатель }\end{array}$} & \multirow{2}{*}{ Норма } & \multicolumn{3}{|c|}{ Контрольная группа } & \multicolumn{3}{|c|}{ Основная группа } \\
\cline { 3 - 8 } & До лечения & $\begin{array}{c}\text { Средний } \\
\text { срок }\end{array}$ & $\begin{array}{c}\text { После лече- } \\
\text { ния }\end{array}$ & До лечения & $\begin{array}{c}\text { Средний } \\
\text { срок }\end{array}$ & $\begin{array}{c}\text { После лече- } \\
\text { ния }\end{array}$ \\
\hline $\mathrm{n}$ & 35 & 43 & 43 & 43 & 46 & 46 & 46 \\
$\mathrm{M} \pm \mathrm{m}$ & $5,42 \pm 0,30$ & $7,10 \pm 0,42$ & $7,16 \pm 0,48$ & $7,52 \pm 0,44$ & $7,28 \pm 0,48$ & $6,70 \pm 0,50$ & $5,67 \pm 0,32$ \\
p1 & - & $<0,01$ & $<0,05$ & $<0,0001$ & $<0,001$ & $<0,05$ & $>0,05$ \\
\%1 & $100,0,0$ & 131,0 & 132,1 & 138,7 & 134,3 & 123,6 & 104,6 \\
p2 & - & - & $>0,05$ & $>0,05$ & - & $>0,05$ & $<0,01$ \\
\%2 & - & 100,0 & 100,8 & 105,9 & 100,0 & 92,0 & 77,9 \\
p3 & - & - & - & - & $>0,05$ & $>0,05$ & $<0,001$ \\
$\% 3$ & & 100,0 & 100,0 & 100,0 & 102,5 & 93,6 & 75,4 \\
\hline
\end{tabular}

Примечания: p1 - достоверность различий данных по отношению к норме, рассчитанный с помощью t-критерия для независимых выборок; р2 - достоверность различий данных по отношению к исходным данным, рассчитанный с помощью t-критерия для зависимых выборок; р3 - достоверность различий данных между группами контрольной и основной в зависимости от срока наблюдения, рассчитанный с помощью t-критерия для независимых выборок.

Общий анализ полученных нами результатов свидетельствует о стимулирующем действии препарата флогензим на протеолитический потенциал организма у больных возрастной дегенерацией макулы. Это является важным патогенетическим фактором в механизме терапевтического эффекта изучаемого препарата при данной патологии, так как известно, что модифицированные молекулы белков вследствие высокого уровня оксидативного стресса могут быть элиминированы из тканей только после их расщепления протеолитическими ферментами. Их принято рассматривать как последний барьер защиты организма от последствий оксидативного стресса.

Можно заключить, что полученные нами результаты обосновывают патогенетическую целесообразность применения препарата системной энзимотерапии - флогензима - в комплексном лечении больных с возрастной дегенерацией макулы.

В офтальмологической литературе сведений о применении флогензима при возрастной дегенерации макулы мы не встретили. В то же время этот препарат применялся в комплексном лечении возрастной ка- таракты на ранних стадиях ее развития [7] и в лечении язвенного бактериального кератита [5]. Лечебный эффект флогензима эти авторы объясняют достоверным стабилизирующим воздействием препарата на белки хрусталика, нормализацией показателей протеолитической и антипротеазной активности крови у больных возрастной катарактой, стабилизацией лизосомальных мембран клеточных структур роговицы, ускорением синтеза и обновления белков роговицы.

\section{Выводы:}

1. Включение флогензима в традиционную схему медикаментозного лечения возрастной дегенерации макулы приводит к существенному повышению протеолитической активности крови больных - на $19,1 \%$.

2. Активность ингибиторов протеолиза у больных возрастной дегенерацией макулы в условиях медикаментозного лечения с включением препарата флогензим заметно снижается - на 22,1 \% относительно исходного показателя. 


\section{ЛИТЕРАТУРА}

1. Астахов Ю. С. Возрастная макулярная дегенерация. Клинические рекомендации. Офтальмология / Ю. С. Астахов, А. Б. Лисочкина, Ф. Е. Шадричев // Под ред. Л. К. Мошетовой, А. П. Нестерова, Е. А. Егорова. М.: ГЭО-Медиа, 2006. - С. 164-188.

2. Венгер Г. Е. Эффективность антиоксидантной терапии у больных склеротической макулодистрофией / Г. Е. Венгер, А. М. Солдатова., В. Н. Косоковская // Матеріали 1-ої міжнародної конференції «Сучасні аспекти судинно-ендокринних захворюваннь органу зору». - Київ, Україна. - 2000. - С. 101-102.

3. Веремеенко К. Н., Голобородько О. П., Кизим А. И. Протеолиз в норме и при патологии / К. Н. Веремеенко, О. П. Голобородько, А. И. Кизим // К.: Здоров'я, 1988. - 200 с.

4. Гланц С. Медико-биологическая статистика. - Пер. с англ. - М., Практика, 1999. - 409 с.

5. Думброва Н. Е., Нестерук Н. И. Изменения пигментного эпителия в патогенезе дистрофий сетчатки, пигментной и поострадиционной / Н. Е. Думброва, Н. И. Нестерук // Тези доп. дев'ятого з'їзду офтальмологів України. - Одеса. - 1996. - С. 365-366.

6. Леус Н. Ф. Состояние антиоксидантного статуса у больных с начальными формами возрастной макулодистрофии / Н. Ф. Леус, А. А. Путиенко, Ю. В. Уманская // III Всеросийский семинар - «Круглый стол» «Макула» - 2008: тез. Докл. - Ростов-на-Дону, 2008. - C. 391-392.

7. Солдатова А. Н. Роль свободнорадикальных, окислительно-восстановительных процессов и видимого света в патогенезе склеротической макулодистрофии и ее дифференцированное лечение: Дис.... д-ра мед. наук.: - Одесса, 1992. - 250 с.

8. Уманская Ю. В. Эффективность нового способа медикаментозного лечения начальной стадии возрастной макулодистрофии: автореф. дисс. канд. мед. наук. 14.01.18 «Одесский НИИ глазных болезней и тканевой терапии им. В. П. Филатова» / Ю. В. Уманская // Одесса. - 2011. - 17 с.
9. Харинцева С. В. Состояние системы «ПОЛ - антиоксидантная защита» у больных макулярной дегенерацией / С. В. Харинцева, Л. А. Голуб // Тезисы докладов. «Макула». - 2008. - 435 С.

10. Beatty S. Macular pigment and age-related macular degeneration / S. Beatty, M. Boulton, D. Henson, H. H. Koh, I. J. Murray // Br. J. Ophthalmol. - 1999. Vol. 83. - P. 867-877.

11. Bergmeyer H. V. Metoden der enzymatischen Analyse / Herausgegeben von H. U. Bergmeyer. - Berlin. 1986. - S. 1605-1609.

12. Davies N. P. Macular pigments: their characteristics and putative role / N. P. Davies, A. B. Morland // Prog. Retin. Eye Res. - 2004. - Vol. 23. - № 5. - P. 533-559.

13. Edwards A. O. Molecular genetics of AMD and current animal models / A. O. Edwards, G. Malek // Angiogenesis. - 2007. - Vol.10. - № 2. - P. 119-132.

14. Liang F. Q. Oxidative stress-induced mitochondrial DNA damage in human retinal pigment epithelial cells: a possible mechanism for RPE aging and age-related macular degeneration / F. Q. Liang, B. F. Godley // Exp. Eye Res. - 2003. - Vol. 76. - № 4. - P. 397-403.

15. Murloy L. Age related macular degeneration: understanding the roles of lipofuscin, macular carotenoid pigments and reactive oxygen species / L. Murloy, D. J. McGarvey., T. G. Truscott., M. Boulton, S. Davies // Invest. Ophthalmol. Vis. Sci. - 1998. - Vol. 39. P.129.

16. Paulus T. V. M. de Jong Age-related macular degeneration / T. V. M. Paulus de Jong // N. Engl. J. Med. - 2006. Vol. 355. - P. 1474-1485.

17. Redmer van Leeuwen The risk and natural course of age-related maculopathy / Redmer van Leeuwen, C. C. W. Klaver, J. R. Vigerling // Arch. Ophthalmol. 2003. - Vol. 121. - P. 519-526.

18. Seddon J. M. Progression of age-related macular degeneration / J. M. Seddon, J. Cote, B. Rosner // Arch. Ophthalmol. - 2003. - Vol. 121. - P. 1728-1737.

Поступила 01.06.2012 Рецензент к. м. н. И. Н. Михейцева

\section{INFLUENCE OF PHLOGENZYME ON BLOOD PROTEOLYTIC ENZYMES ACTIVITY IN PATIENTS WITH AGE-RELATED MACULAR DEGENERATION \\ Onischenko A. A., Savko V. V., Parhomenko T. V.}

Clinical and biochemical studies are carried out in 89 patients with degeneration of the age-related macula: the main (46 patients) and control group (43 patients). The application of phlogenzyme in the main group increases the indices of total proteolytic activity by $36,6 \%$ and reduces the indices of antiprotease activity by $24,6 \%$ in comparison with the control group after treatment. The results obtained substantiate the prospect of application of the preparations of systemic enzymotherapy in the complex treatment of degeneration of the age-related macula. 